\title{
THE
}

\section{A Sense of Belonging Among College Students With Disabilities: An Emergent Theoretical Model}

\author{
Annemarie Vaccaro \\ University of Rhode Island, avaccaro@uri.edu \\ Meada Daly-Cano \\ University of Rhode Island \\ Barbara M. Newman \\ University of Rhode Island, bnewman@uri.edu
}

Follow this and additional works at: https://digitalcommons.uri.edu/hdf_facpubs

Terms of Use

All rights reserved under copyright.

\section{Citation/Publisher Attribution}

Vaccaro, A., Daly-Cano, M., \& Newman, B. M. (2015). A Sense of Belonging Among College Students With Disabilities: An Emergent Theoretical Model. Journal of College Student Development, 56(7), 670-686. doi: 10.1353/csd.2015.0072

Available at: http://dx.doi.org/10.1353/csd.2015.0072

This Article is brought to you for free and open access by the Human Development and Family Science at DigitalCommons@URI. It has been accepted for inclusion in Human Development and Family Science Faculty Publications by an authorized administrator of DigitalCommons@URI. For more information, please contact digitalcommons-group@uri.edu. 


\section{PROJECT MUSE*}

\section{A Sense of Belonging Among College Students With Disabilities: An Emergent Theoretical Model}

Annemarie Vaccaro, Meada Daly-Cano, Barbara M. Newman

Journal of College Student Development, Volume 56, Number 7, October 2015, pp. 670-686 (Article)

Published by Johns Hopkins University Press DOI: 10.1353/csd.2015.0072

$\Rightarrow$ For additional information about this article http://muse.jhu.edu/journals/csd/summary/v056/56.7.vaccaro.html 


\title{
A Sense of Belonging Among College Students With Disabilities: An Emergent Theoretical Model
}

\author{
Annemarie Vaccaro Meada Daly-Cano Barbara M. Newman
}

Higher education research suggests that the development of a sense of belonging is key to academic success and persistence, yet we know little about how first-year students with disabilities develop a sense of belonging as they transition into and through their first year in postsecondary environments. Themes from a grounded theory study of 8 college students, most of whom had invisible disabilities, provided the foundation for an emerging model of belonging. Student narratives suggest there are interconnections between the development of a sense of belonging, self-advocacy, social relationships, and mastery of the student role for first-year students with disabilities.

In the postsecondary realm, a sense of belonging has been associated with academic motivation, success, and persistence (Freeman, Anderman, \& Jensen, 2007; Hausmann, Schofield, \& Woods, 2007; Hoffman, Richmond, Morrow, \& Salomone, 2002/2003). Many scholars argue that developing a sense of belonging is an especially necessary, but challenging, endeavor for students from historically marginalized social identity groups (Hurtado \& Carter, 1997; Maestas, Vaquera, \& Zehr, 2007; Strayhorn, 2012). Students with disabilities are a growing population of historically marginalized students with $25 \%$ of youth with disabilities pursuing education after high school (Wagner, Newman, Cameto, Garza, \&
Levine, 2005), yet we know very little about how college students with disabilities develop a sense of belonging as they transition to postsecondary education.

This article presents findings about the sense of belonging among 8 first-year students who self-identified as having a documented disability. With one exception, participants had invisible disabilities, meaning their disability was not readily apparent to others (Evans \& Herriott, 2009). The students were part of a larger grounded theory study that focused on how students from historically marginalized social groups develop a sense of belonging during their first year on campus. Analysis of student narratives revealed differences among subpopulations of study participants and point to three themes that contribute to a sense of belonging for college students with disabilities: self-advocacy, mastery of the student role, and social relationships. While we initially set out to determine what contributes to student's self-reported sense of belonging, we learned that our emergent themes and belonging seemed to influence each other. Student narratives suggest that developing a sense of belonging also helps advance students' self-advocacy, mastery of the student role, and social relationships. Data provided the foundation for an emergent model of belonging for college students with disabilities.

Annemarie Vaccaro is Associate Professor of Human Development and Family Studies, College Student Personnel Program; Meada Daly-Cano is a doctoral student of Psychology; Barbara M. Newman is Professor Emeritus of Human Development and Family Studies; each at the University of Rhode Island. This research was supported in part by a ACPA AOFYE Commission Grant. We would like to thank the Disabilities Services for Students Office and the student research team (Alex Butler, Indrawati Liauw, Brenda McGill, and Allison Seperack) from the University of Rhode Island. 


\section{LITERATURE REVIEW}

The following literature review provides highlights of the research on belonging as it relates to success in postsecondary education, the educational contexts for students with disabilities under Individuals With Disabilities Education Act (IDEA; 1975), and the concept of self-advocacy as a key process for success in the transition from high school to college.

\section{Belonging}

Much of the postsecondary belonging literature (Hurtado \& Carter, 1997; Maestas et al., 2007; Strayhorn, 2008) builds upon Tinto's (1987) model of student retention which suggested that students leave universities if they fail to become integrated into social and academic life. Other literature describes the sense of belonging as being fostered specifically through campus involvement (Hurtado \& Carter, 1997; Johnson et al., 2007; Strayhorn, 2012). Common to the literature is an emphasis on psychological feelings of fitting in, acceptance, and support from a group or community (Strayhorn, 2012).

Strayhorn (2012) suggested a "sense of belonging may be particularly significant for students who are marginalized in college contexts" (p. 17). There is an emerging body of literature about the development of a sense of belonging for students of color (Hausmann et al., 2007; Hurtado \& Carter, 1997; Johnson et al., 2007; Locks, Hurtado, Bowman, \& Oseguera, 2008; Núñez, 2009; Strayhorn, 2008/2012), and some research has suggested they experience less of a sense of belonging than their White counterparts (Johnson et al., 2007; Strayhorn, 2008). Other studies have examined the sense of belonging for other historically marginalized student groups, such as gay students (Strayhorn, 2012) and students from lower-socioeconomic statuses (Ostrove \& Long, 2007), yet, we know very little about the development of a sense of belonging for college students with disabilities.

Strange (2000) argued that a sense of belonging for students with disabilities results from physically accessible spaces with psychological features that engender a sense of safety. Literature on the transition from high school to college for students with disabilities offers conflicting insight about their postsecondary experiences (Adams \& Proctor, 2010; Shepler \& Woosley, 2012; Wessel, Jones, Markle, \& Westfall, 2009). For instance, Adams and Proctor (2010) found that students with disabilities had difficulties adapting to college and considered dropping out. Conversely, Shepler and Woosley (2012) found that students with disabilities did not have significantly different experiences than their nondisabled peers regarding transition issues, such as social integration, academic mastery, institutional attachment, or home sickness.

Belonging and Relationships. Scholars have long argued that social acceptance is the foundation for a sense of belonging (Baumeister \& Leary, 1995; DeWall \& Bushman, 2011), and higher education studies have affirmed the significance of supportive relationships (Hausmann et al., 2007; Hoffman et al., 2002/2003; Hurtado \& Carter, 1997; Johnson et al., 2007; Strayhorn, 2008). In fact, Hoffman et al. (2002/2003) argued that perceived peer support should be one of the key factors used to assess sense of belonging. Hausmann et al. (2007) found peer support to be especially important to increasing the sense of belonging in African American college students. In his work with gay men of color, Strayhorn (2012) found relationships with fictive kin influenced belonging. With one exception (Johnson et al., 2007), research has also affirmed that positive interactions and perceived support from faculty increase students' sense of belonging (Freeman et al., 2007; Hausmann et al., 2007; Hoffman et al., 
2002/2003; Hurtado \& Carter, 1997).

The limited literature about the collegiate experiences of students with disabilities reveals conflicting findings about relationships with educators (Adams \& Proctor, 2010; Ashby \& Causton-Theoharis, 2012; Barnard-Brak, Lechtenberger, \& Lan, 2010; Megivern, Pellerito, \& Mowbray, 2003; Olney \& Brockelman, 2003; Troiano, 2003). Two studies suggest that students with disabilities have difficulty developing positive relationships with, and/or obtaining necessary supports from faculty (Barnard-Brak et al., 2010; Olney \& Brockelman, 2003), while another found almost exclusively positive relationships between faculty and students with disabilities (Troiano, 2003). Literature regarding peer relationships is less divided and less positive. Megivern et al. (2003) found that almost a third of students with psychiatric disabilities reported difficulties with social life during college, including feeling isolated, experiencing stigma and discrimination, and being unable to make friends. In another study, students with disabilities scored lower on measures of social adjustment to college than their nondisabled peers (Adams \& Proctor, 2010).

Belonging and Academic Success. In higher education settings academic motivation, academic integration, and academic persistence have been associated with a sense of belonging at the classroom level (Freeman et al., 2007; Hausmann et al., 2007; Parker \& Flowers, 2003); however, academic mastery has been researched less frequently. A mastery orientation reflects students' desires to seek out challenges, a commitment to learning new strategies that will support their learning, and a willingness to use feedback and resources in order to achieve new levels of comprehension (Ames, 1992). Summers and Svinicki (2007) found that students gave a higher rating to their academic mastery and classroom sense of belonging in courses where teachers used interactive learning techniques and encouraged cooperation as opposed to traditional, lecturestyle classes. In a longitudinal study of college students, Pittman and Richmond (2007) found increases in a sense of belonging over the course of the first year were associated with increases in scholastic competence, which included mastery of course work.

\section{Educational Context of Disability}

The Americans With Disabilities Act of 1990 (ADA) defines a disability as a physical or mental impairment that substantially limits a major life activity such as "communicating and working as well as caring for oneself, performing manual tasks, seeing hearing, eating, walking, standing lifting, bending, speaking, and breathing" (Chapter 126, Sec. 12102, ADA, 1990). In 2008, the ADA was amended to include learning related activities such as concentrating, reading, and thinking (Americans With Disabilities Act Amendments Act [ADAAA], 2008). A mental illness can be categorized as a disability if it impairs one's ability to cope with the above mentioned major life activities (Belch, 2011). These definitions show that a disability can be visible or invisible (Evans \& Herriott, 2009).

Students with disabilities have varying levels of access and support throughout K-16 educational settings. Laws such as IDEA (1975) ensure that students are provided with Free and Appropriate Public Education (FAPE) through high school graduation or age 21 . Once students graduate from high school or reach age 21, they are not guaranteed a FAPE; however, the 2004 IDEA Improvement Act specified that postsecondary institutions should be accessible and provide accommodations for students with disabilities. While there are accommodation guidelines (Bryan \& Myers, 2006; Burke, Friedl, \& Rigler, 2010), Belch and Marshak (2006) found that student affairs divisions in particular, and universities in 
general, were not always prepared to support students with disabilities.

Under IDEA, primary and secondary schools are responsible for identification, assessment, and development of educational plans for students with disabilities. Services are provided so students can reach the educational outcomes outlined in their Individual Education Programs (Stodden, Conway, \& Chang, 2003). The process of receiving accommodations significantly changes once students enter postsecondary settings where they must self-identify, undergo assessment, and seek out assistance to receive accommodations or services. This shifting of responsibility from the school to the student requires students take on a self-advocacy role to obtain services (Stodden et al., 2003).

\section{Self-Advocacy}

Multiple researchers have found that selfadvocacy is critical in the transition to, and persistence through, postsecondary education (Adams \& Proctor, 2010; Daly-Cano, Vaccaro \& Newman, 2015; Getzel \& Thoma, 2008; Hadley, 2006; Janiga \& Costenbader, 2002; Thoma \& Wehmeyer, 2005; Webster, 2004). Despite these benefits, some students with disabilities come to college unprepared to self-advocate because of past reliance on parents, special education teachers, and a secondary school system that did not require self-advocacy (Janiga \& Costenbader, 2002). Daly-Cano et al. (2015) found some students with disabilities proactively self-advocated, while others reactively or retrospectively selfadvocated only after a negative incident or failure occurred.

Self-advocacy is the ability to communicate one's needs and wants and to make decisions about the supports necessary to achieve them (Stodden, 2000). Key components of self-advocacy are knowledge of self, knowledge of rights, ability to communicate, and ability to be a leader. Knowledge of self refers to understanding one's preferences, goals, learning style, strengths, weaknesses, accommodation needs, and the characteristics of one's disability; while knowledge of rights refers to understanding personal rights, community rights, educational rights, steps to correct violations, and steps to advocate for change (Test, Fowler, Wood, Brewer, \& Eddy, 2005). Communication and leadership include the ability to convey information to receive accommodations and support.

Researchers have identified specific selfadvocacy skills that help students succeed in higher education, including utilizing tutoring labs and disability services, forming relationships with instructors, and having a support system on campus (Adams \& Proctor, 2010; Getzel \& Thoma, 2008). One study found that disclosing one's disability and requesting accommodations were common themes discussed by academically successful students with disabilities (Barnard-Brak et al., 2010), yet researchers have found that students often choose not to disclose their disability upon entering college (Belch 2011; Hadley, 2006; Megivern et al., 2003; Olney \& Brokelman, 2003; Wagner et al., 2005; Vickerman \& Blundell, 2010). One of the reasons for the lack of disclosure is the prevalence of negative attitudes toward individuals with disabilities (Olkin, 1999). People with disabilities "are constantly told by the dominant culture what they cannot do and what their place in society is" (Charlton, 2006, p. 225), and many individuals internalize this oppression and "come to believe they are . . . less capable than others" (Charlton, 2006, p. 220).

This sociopolitical educational context for disability, combined with the literature on self-advocacy, academic mastery, and belonging for college students, informed this grounded theory study. While these separate bodies of literature were gleaned from disparate fields 
and disciplines, interconnections among these concepts led us toward a more comprehensive understanding of belonging for students with disabilities.

\section{METHOD}

Grounded theory emphasizes theory building through a complex and emergent process as opposed to reliance on a priori assumptions and hypotheses that produce narrowly limited theories (Glaser \& Strauss, 1967). Since grounded theory is designed for generating theories of process, change, or sequence, this method was ideal for our study of belonging. The emergent theory presented in this manuscript is grounded in data that surfaced from student narratives about the development of a sense of belonging during the first-year of college. Overarching research questions for the study included: How do firstyear students from historically marginalized social identity groups define and describe the development of a sense of belonging? For the purposes of the study, we defined individuals as belonging to a historically marginalized social group if they identified as being: a person of color, a person with a disability, gay, lesbian, bisexual, transgender, or an individual whose religious background was not Christian. In this study, we found the experiences of eight self-identified students with disabilities to be distinctively different from other marginalized social groups.

The setting for the study was a midsize, public research university located in the eastern part of the United States. The school enrolled approximately 13,000 students, 1,200 of whom self-identified with the institution as having a documented disability. These students are served by a Disability Services office that coordinates accommodation and support services.

Grounded theory utilizes theoretical sampling, which allows the researcher to select participants who can best contribute information to the evolving theory (Glaser, 1992). We recruited study participants in locations where we were likely to find firstyear students from historically marginalized social groups (e.g., LGBT center, women's center, disability services, Hillel). Students who responded to electronic and in-person recruitment were provided detailed study information and invited to a series of two individual interviews. All 30 students who volunteered to participate in the study completed an initial interview during the fall semester, and 20 returned for the second interview in the spring semester. Eight students with disabilities participated in the fall and seven returned for a spring interview. Participants were diverse in age (18-32 years old), major, and disability, but not by gender. Only two men and six women participated. Students self-reported their disabilities as Asperger's syndrome, bipolar disorder, dyslexia, obsessive-compulsive disorder, retinopathy of prematurity, ulcerative colitis, and two had learning disabilities. With one exception, these disabilities were mostly invisible to others (Evans \& Herriott, 2009).

\section{Data Collection and Analysis}

Data collection and analysis were completed by a research team that consisted of two full-time faculty members, two doctoral students, and two master's students from Psychology and Human Development and Family Studies. The all-women research team was racially diverse, with three White, two Black, and one Asian members. Two members self-identified as a sexual minority. None selfidentified as a person with a disability. Each team member had a research interest in college student development.

The research team met every other week for a year. To ensure rigorous data collection 
and analysis, graduate students received training about grounded theory methods, interviewing skills, and coding processes. The training provided students the opportunity to practice interviewing and coding and to receive detailed feedback from the faculty members before engaging in real-life processes. Student interviewers were also given feedback after completing their first live interview.

In-depth interviews are often used as a vehicle for data collection in grounded theory research (Glaser, 1992; Glaser \& Strauss, 1967). Members of the research team individually interviewed between four and seven students. Semistructured, individual interviews served as the primary mode of data collection for this study. Glaser and Strauss warn that highly structured interviews force data to fall within preconceived realms of the researcher's reality. In the first round of interviews, each interviewer asked broad questions about the ways students developed a sense of belonging. Fall interview questions included: How do you define what it means to belong? Tell me about anything that happened in your first few weeks that influenced your sense of belonging. Were there any experiences or people who were especially important in influencing your sense of belongingpositively or negatively?

The spring protocol was more focused because we used specific responses and emergent themes from the first round of interviews to shape the questions. For instance, we asked students questions such as, In the fall, you described as being especially salient to your belonging. Can you tell me if, and how, your experiences with influence your sense of belonging today? Moreover, we added questions that allowed us to delve into emergent themes from the fall interviews which led to our final categories of mastery, self-advocacy, and social relationships. To explore emerging ideas that led to the mastery category, we asked: Can you tell me, if and how, your first semester grades influenced your sense of belonging? and Think about something you are especially good at. How, if at all, does your mastery in that area shape your sense of belonging? To more deeply explore self-advocacy, we asked: If you could go back in time, what would you do differently/ similarly to establish a sense of belonging? Finally, we asked: How do your relationships influence your sense of belonging today as opposed to in the fall? If those relationships have changed, the influence on your sense of belonging may also have changed. Can you talk about that?

All interviews were audio recorded and transcribed for analysis. A hallmark of grounded theory is the concept of constant comparative data analysis (Glaser, 1992; Glaser \& Strauss, 1967; Strauss \& Corbin, 1990, 1998). Creswell (2007) refers to the process as a zigzag, whereby researchers gather information, analyze it, and use the analysis to shape further data gathering. As researchers, we engaged in this back-andforth movement between data collection and analysis throughout the research process. The team met every other week to discuss themes that emerged during the interviews. Each member of the research team kept memos about the research process and emergent themes. Memos are a "researcher's record of analysis, thoughts, interpretations, questions, and directions for further data collection" (Strauss \& Corbin, 1990, p. 110). Memos guided research team discussions and served as a method of triangulation for codes gleaned from interview transcripts.

Open, axial, and selective coding were used to analyze the transcripts (Strauss \& Corbin, $1990,1998)$. Each member of the research team independently read the transcripts in their entirety, noting key topics in the form of potential open codes. Only topics that yielded $100 \%$ agreement among the research team were 
retained. Once the lengthy list of open codes were decided upon, we used axial coding to connect like categories into eight broad themes under which all open codes were subsumed. This process of data analysis was repeated for the second round of interviews. When open and axial coding were complete for both the fall and spring interviews, we engaged in selective coding to connect key categories and build a story about the sense of belonging for students with disabilities. That process involved "selecting the core category, systematically relating it to other categories, validating those relationships [through discrepant case analysis and confirming examples], and filling in categories that need further refinement and development" (Strauss \& Corbin, 1990, p. 116). The core category of belonging was related to three categories: self-advocacy, mastery of the student role, and social relationships.

To ensure trustworthiness and credibility of study findings, a variety of qualitative verification methods were implemented (Creswell, 2007; Jones, Torres, \& Arminio, 2006). For purposes of corroboration, data from the initial interviews were triangulated with the second. The research team also engaged in analytic triangulation whereby we coded each transcript independently and then revised the codes as a group (Patton, 2002). Once the axial coding frame for each round of interviews was solidified, the research team re-read the transcripts and assigned axial codes. We only retained coded quotes that yielded 100\% agreement from the researchers. Negative case analysis was used when a participant's experiences ran counter to our emergent codes (Creswell, 2007). Emergent themes from the interviews were used for member checking. After the spring interview, students were invited to offer feedback on both the themes and research process. Peer reviews from expert disability services professionals were also utilized to ensure credibility of our emergent themes and model.
The research team utilized reflexivity, which is especially important in studies where members of privileged identity groups study those who experience oppression (Jones et al., 2006). Although the researchers self-identified as members of historically marginalized social groups (e.g., by gender, race, sexual orientation), none of us identified as having a disability. Throughout the research process, we engaged in reflexive discussions about our assumptions, concerns, and questions related to the development of a sense of belonging for first-year students with disabilities. For instance, we discussed, if and how, our socialization led to subjectivities about students with disabilities (Charlton, 2006). We wrestled with three key subjectivities throughout the process including: (a) assumptions that students with disabilities constantly struggled to be successful; (b) expectations that belonging would largely relate to the ease or difficulty obtaining accommodations; and (c) notions that students would not want to talk extensively about their conditions (e.g., irritable bowel syndrome, mental health). These subjectivities were rooted in our own lack of awareness as individuals with privilege. They were also informed by literature that emphasizes student struggles and deficits, accommodations, and hesitation to disclose due to stigma. We addressed these subjectivities at each research team meeting by acknowledging our assumptions and challenging our subjectivities with actual student narratives, most of which ran counter to these perspectives. During data analysis and writing we revisited these subjectivities to ensure that our underlying assumptions and knowledge of prior literature did not overshadow actual student stories.

\section{FINDINGS}

Analysis of student narratives pointed to three themes that contributed to a sense of belonging 
for college students with disabilities. First, sense of belonging was intricately tied to students' ability to self-advocate. Second, students discussed their need to master the student role. Third, students spoke of the importance of supportive relationships. Moreover, as students developed a sense of belonging, they enhanced their ability to master the student role, self-advocate, and further develop social relationships. In the following sections, we illustrate how each emergent theme impacted belonging and how increased belonging, in turn, influenced the three themes. Figure 1 summarizes these findings in an emergent theoretical model of belonging.

\section{Self-Advocacy and Belonging}

All students in this study described how the ability to successfully self-advocate inside and outside the classroom shaped their sense of belonging on campus. During the interviews, students explained how their self-advocacy was rooted in a self-awareness of their disability and corresponding needs. It also included the ability to act in ways that fulfilled their needs. Lisa, a student with bipolar disorder, explained her understanding of her disability and where she initially learned effective strategies to manage her condition. In college, she demonstrated knowledge of self and her disability needs (i.e., self-advocacy) when describing particular actions (e.g., exercise, therapy regimen, campus involvement, sleep) that helped her feel comfort, success, and belonging at the university:

I did go to the outpatient hospital and they taught me all different kinds of tactics. ... I know that physical activity needs to be in my life, and my therapist needs to be there and my meds, and so if I have all those 3 things and like sleep, then everything falls into place. ... If my mind is going at a pace of like 190 miles an hour, I need to ... go for a run, or if I kick box it kind of relaxes me a little bit with some tension [release].... I can't meditate when I am too amped up.

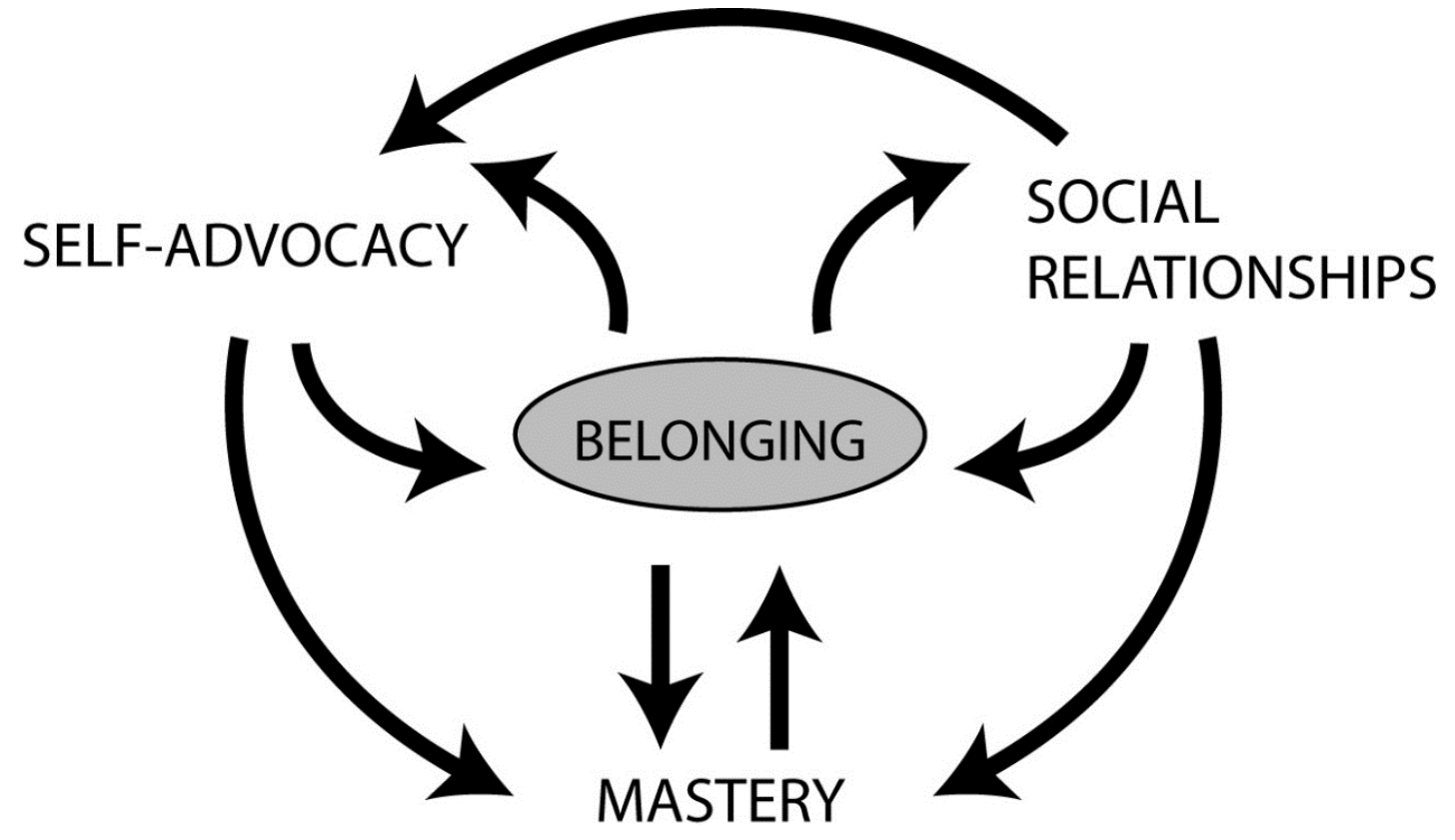

Figure 1. Theoretical Model of Belonging for College Students With Disabilities 
When asked, "What here at [this university] has become important to your sense of belonging?" Lisa's response included, "being active and involved in outdoor activities with the outing club" and "studying in the library and just being outside with my friends is important too." These influences on Lisa's sense of belonging were directly tied to her selfadvocacy efforts described above. Self-advocacy in the fall semester paid off. In her second interview, Lisa described her sense of belonging as an 8 out of 10 , saying, "I feel pretty good here ... and I found my niche [in the outing club]." In that outdoor club, students were "doing their best in every aspect of their healthy life ... getting good grades and having balance like me." Lisa's capacity to be selfaware about her needs (e.g., physical activity, authentic friends, balance) and reflective about her values (healthy lifestyle, good grades) contributed to her self-advocacy efforts, including getting involved in the outing club. This self-advocacy was integral to finding her niche and corresponding sense of belonging.

During the spring interview, Naomi explained how flare ups of her ulcerative colitis and inflammatory bowel disease (IBD) took a toll on her sense of belonging. She lamented how flare-ups "set me back [on my sense of belonging] a little bit"; yet, Naomi was inspired to self-advocate so that she could "go forward now." Part of increasing her belonging was not allowing IBD to prohibit her from socializing. She had to relearn her limits regarding dining hall eating. She stated, "Yeah I have everything under control now. I figured some things out, brought some more food from home." She also explained how her self-advocacy efforts included making the right decisions in the dining hall and "keeping track of all the bathrooms" on campus, all of which allowed her to feel comfortable going to university events, freely socializing, and in turn, feeling a sense of belonging.
Narratives of self-advocacy and belonging also included the strategies participants used to communicate their accommodation needs to others. Students described the importance of visiting disability services counselors, utilizing tutoring services, and providing faculty members with their accommodation letters. They also worked with faculty members over the course of the semester to ensure that their accommodations were provided. The interviewer asked, "As someone with a learning disability, how do you develop a sense of belonging?" Jennifer responded that selfadvocating for support and resources from staff and faculty enhanced her belonging: "I think it's just really seeking stuff out [from faculty and staff]." Later in the interview, she described how self-advocacy meant putting herself "out there to ... teachers and explain[ing]" about her disability so that she could get what she needed. When she got what she needed, she felt more inclined to belong in the class and also at the university.

Melissa also talked about how her selfadvocacy efforts inside and outside the classroom helped her feel as if she belonged. For instance, her self-advocacy efforts with the conductor and peers increased her sense of belonging in the marching band:

Honestly, it's been pretty good. As long as I just tell people that I'm visually impaired, they're really quick to adapt, especially ... the head of the band. He's been really good about getting music to me early so I can enlarge it. The kids are really good whenever we're like setting drill on the field, which is where we make formations. Like they all know how to communicate with me now.

The interviewer asked, "Were there any experiences or people who were especially important in influencing your sense of belonging-positively or negatively?" In response, Melissa described how the 
marching band was a key influence on her sense of belonging.

\section{Mastery and Belonging}

All students described the importance of successfully mastering various demands of the role of college student in order to feel a sense of belonging on campus. We came to understand the student role as mastery of academic tasks and earning good grades; however, it also includes "feeling like a college student" by blending in with peers, being viewed as a legitimate student, and gaining recognition for academic success.

Mastery of the student role related directly to students' ability to achieve high grades. Jennifer explained that doing well in classes made her feel as if she were in the right place: "I think I have solid Bs in my classes now, which I'm thrilled with. ... It's an amazing feeling. So, ... it's definitely . . . about what I have accomplished. And I am happy here." For Barry, a student with obsessive-compulsive disorder, mastery of the student role was an ongoing process directly connected to grades. He explained how one class detracted from his sense of belonging, because he felt like he was set up for failure instead of success:

Walking into chemistry in my first class, and one of the first things that my professor said was something about a $20 \%$ fail rate. ... That's a bit overwhelming. It didn't seem to bother the professor, but that that many people would fail bother[ed] me. ... It's definitely my least favorite class so far.

In addition to earning good grades, students also explained how mastery of the student role was reflected in their ability to accomplish specific academic tasks (e.g., tests, study methods, assignments). Jennifer explained her strategy of starting at the back of the test and working forward: "So by starting at the back I was fine. It is very weird and there is no rhyme or reason to it [but it works for me]." Similarly, Ethan described how he developed an effective study method for biology: "I had a study method that I found was really effective. I think that makes me feel more inclined to belong in biology."

Beyond attaining good grades and accomplishing specific academic tasks, mastering the student role also meant "fitting in" and feeling like "just another student." Students with disabilities described how their sense of belonging was tied to their ability to integrate seamlessly into collegiate life: blending in with the larger student body was one way to achieve such integration. Lisa explained how she felt a sense of belonging when she studied in the library or at a coffee shop and knew that the other people around her were studying too. Like her peers, Lisa was doing things she felt she needed to do to master the student role. "That sense of belonging, I guess, and just trying to just like do my work with the rest of the student body — so that's one thing that is critical toward my development at [college]." For students with disabilities, being seen as a legitimate student was essential to a sense of belonging. Jennifer explained that she had not yet been accepted into the Nutrition program because of low grades. She enrolled as a nonmatriculating student to demonstrate that she did belong in the program and that she could succeed academically if given the chance. She said, "I'm trying to prove a point ... probably more for me, that I can do it."

Students explained how their identity as a student and sense of belonging increased when faculty and peers recognized their academic success. Positive recognition from peers and faculty helped students feel like a legitimate college student. This aspect of the student role may be especially significant given the stigma and stereotypes associated with having a disability (Charlton, 2006). When Emily spoke up in class, she enjoyed the response 
from peers: "Oh wow! You knew this answer!" Similarly, Ethan said, "I think belonging comes if I get respected for how well I do." Ethan also described how his sense of belonging was negatively affected when others assumed he had low academic skills and did not belong at college. He said, "Sometimes it bothers me. Sometimes I find that with my academic skills, they always say that I am disabled, even if I am doing perfectly fine in school, just because I have Asperger's." Jennifer concurred, “Just because I have a disability, doesn't mean I am not intelligent. It just means I don't think like you think. . . . It's really evident that my grades do not reflect what I understand and my intelligence."

\section{Social Relationships and Belonging}

All students discussed the importance of supportive relationships to the development of a sense of belonging. Students described a variety of ways that they connected socially with peers in classrooms, residence halls, and through student involvement. Melissa proudly explained how she fits in socially with her classmates, those with disabilities and those without. Through her relationship with another student with a mental illness, Lisa found a valuable social connection. She said, "I know that there are other people that have mental illnesses here too. I have a friend that does have one. And so I talk with her about things. And I relate with her about certain things." Ethan and Jessica, however, were still searching for more meaningful social connections. In high school, Ethan developed friendships with other students with Asperger's. In his quest to increase his social connections and sense of belonging, he attended a social skills group:

Every two weeks there is going to be somebody else with Asperger's there. So that makes me [happy] -it improves my belonging a bit. ... I thought it was neat to meet somebody who is similar to me. ... I don't usually find people who are similar to me. I think there is a good chance I will make some friends this semester.

Jessica also hoped to socially connect with people like her: "I haven't met anyone else with dyslexia here. And, it kind of sets me apart. That would be one thing that kind of makes it harder to belong." However, during her second interview, Jessica explained how she forged close social relationships with nondisabled students who she described as "empathetic." In fact, some of her "best friends" regularly volunteered to read chapters aloud to her, even if they had already done the reading for class.

\section{Interrelationships Among Three Themes and Belonging}

One of the benefits of a study design that includes multiple interviews is that researchers can document change over time. During the second interview all but one student explained how their sense of belonging had increased between the fall and spring semesters. Narratives from those second interviews suggest that the process of belonging is complex. We showed how the three emergent themes influenced belonging. During the spring interviews, students explained how increased belonging helped them self-advocate, master the student role, and develop more numerous and deeper relationships. As such, the sense of belonging appears in the center of Figure 1 with two directional arrows connecting belonging to each of the three emergent themes. In the following paragraphs, student narratives are used to highlight the ways increased belonging influenced each of the three themes and how they are related to each other.

Students described how having a sense of belonging contributed to their confidence and ability to self-advocate. This connection is shown by the arrow from belonging to self- 
advocacy. Barry shared, "When I feel a sense of belonging ... I am able to step up and get what I need in order to do well." Jessica learned "you just have to take care of yourself," and an increasing sense of belonging allowed her to "stick to it" and self-advocate even when she was "physically sick" or downright exhausted. Jennifer also explained how as her sense of belonging began to increase, she was more likely to visit the disability services office beyond the required times. In fact, she took the initiative to schedule an extra meeting with the office just to check in after she recognized strategies that worked and those that did not:

At the end of last semester I wanted to meet with [Disability Services] because I wanted to debrief from the semesterlike how was it going. ... It was good for me because [I had learned and could communicate,] "This is what works for me" [or] "This is what is not working."

The arrow from belonging to mastery in Figure 1 shows that as students' sense of belonging increased, they often felt their sense of mastery grow. Naomi explained how being part of the marching band contributed to her sense of belonging. In turn, that sense of belonging helped her master her instrument and her role as a student in the campus band. As Jessica's sense of belonging increased, she felt more comfortable mastering the student role by acting like a "typical college student." During her interview, she confidently explained how she had mastered skills essential to the student role, such as time management and prioritization: "College is like $100 \%$ time management. You know? Everyone says that, but it's so true. I'm not a procrastinator." Barry explained how average grades (e.g., mastery) in the first semester increased his sense of belonging. Having a sense of belonging in the second semester contributed to his determination to further master the student role. During the second semester, he earned higher grades: "It just felt like the hard work paid off." In sum, as students' sense of belonging increased, they approached the challenges of their student role with new confidence.

Increased belonging also seemed to contribute to increased or deepened relationships. For instance, Barry shared, "I am able to branch out and meet new people. And when I feel a sense of belonging, I am able to really try to connect, because I can. I am able to not just be shy." As Naomi's sense of belonging grew, so did her confidence in being honest with friends. Early in the year, she did not talk about her inflammatory bowel disease with peers. By spring she was comfortable being candid about her limits with friends. She found her good friends were happy to accommodate her needs. Naomi explained:

Some days I don't feel good and on others I feel good. ... Sometimes my friend asks if we can have an ice cream night on that night. But I can't have too much milk because that exacerbates [my IBD]. So I have to decline. Pretty much we just don't [go for ice cream that night. But] maybe she will come over and we'll just watch a show or something.

Participants also described connections between social relationships, self-advocacy and mastery. The arrows forming the outer ring in Figure 1 reflect connections between the emergent themes. Students explained how social relationships with faculty and peers helped them develop effective selfadvocacy skills and mastery of the student role. Through reciprocal peer relationships, Emily gained a deeper sense of confidence in her ability to self-advocate. She said, "If I hear advice from someone, then I can give it to [other students] and see that they are doing good in what I helped them with. So that can kind of help me also." Jennifer described how a relationship with a supportive 
chemistry professor helped her gain the confidence and skills to self-advocate which, in turn, influenced her academic mastery. This professor spent time getting to know Jennifer. Even in a 300-person lecture hall, she knew Jennifer's name and regularly asked, "How are you doing?" This connection gave Jennifer the confidence to reach out to the professor when she needed help:

My first test, I got a 78. I was kind of bummed, because I had busted my ass. I sent her an e-mail. And, I was like, "All right, I want to spend time with you. I want to see what I did wrong. How do I fix it?" [During the conversation] she's like, "You can do it." It was like a cheerleading section.

Through self-advocacy efforts, Jennifer gleaned relational support from the professor. In turn, Jennifer felt empowered to increase her mastery of the material. She shared, "I think [professor name] makes me feel so empowered."

Through relationships with other students with disabilities, participants shared advice and learned from each other's successes and failures. In turn, they mastered the student role. The arrow connecting relationships and mastery reflect this phenomenon. Jennifer explained how a friend with a learning disability helped her master study skills:

I have made a really good friend here. ... He's got a learning disability. . . We drive in together and we sometimes study together. So I am like, "Quiz me." He's like, "I don't understand how you made that connection." . . . But it's one of those things because we both have learning disabilities it's very cool to see how I make the connection and I get to the same ending, and he makes a connection and gets to the same ending.

While she was happy with this supportive relationship, Jennifer wished that the university would be more intentional in helping students with disabilities connect so that they could collaboratively hone their academic mastery: "Yeah, it would be nice to have a student disability [group] ... some kind of connection for kids."

Student experiences suggest that effective self-advocacy skills contribute to mastery of the student role. This relationship is shown by the arrow between self-advocacy and mastery. When she was struggling with her computer homework, Melissa used her newly acquired self-advocacy skills to ask for help from "one of the techie guys in my hallway." She explained, "When I tried it on my own and that didn't work, I had to go to Plan B.” Her self-advocacy skills prompted her to realize the need for Plan B which, when implemented, allowed her to successfully complete the homework assignment. Jessica described how learning to self-advocate was an essential aspect of life and something that individuals learn in order to master the student role. She said, "I had to like, self-advocate, you know? But that's obviously a skill you need for life and that's a skill you learn in college. So, I was happy I was doing that [self-advocating]."

\section{DISCUSSION AND IMPLICATIONS}

This study adds to the literature by offering a theoretical model that reflects the process through which students with disabilities developed a sense of belonging. Only one other study, Strayhorn (2012), offers a multidimensional image of belonging. While Strayhorn's model effectively describes a variety of phenomena that influence the sense of belonging for diverse students, it was not based upon studies of students with disabilities; thus, it does not adequately describe the process of belonging described by our participants. In fact, most belonging literature does not highlight process, but instead emphasizes the relationship between belonging and particular 
variables such as persistence, academic success (Freeman et al., 2007; Hausmann et al., 2007; Hoffman, 2002/2003), or campus involvement (Hurtado \& Carter, 1997; Johnson et al., 2007; Strayhorn, 2012).

Practitioners who emphasize only one of our emergent themes (e.g., relationship building, academic mastery, or self-advocacy skills) may be ineffective in assisting students to develop a sense of belonging. By law, higher education institutions are only required to provide reasonable accommodations for students with disabilities. This narrow requirement can limit higher education institutions to merely emphasize accommodations (e.g., extended time, interpreters, accessible classrooms), as opposed to proactive initiatives that can promote the development of belonging. Disability services professionals should partner with academic and student affairs colleagues in other functional areas (e.g., residence life, orientation, student activities) to design programs, policies, and services that promote self-advocacy, mastery, and social relationships for students with disabilities. By simultaneously attending to all of these variables, professionals can support students in the process of developing a sense of belonging.

Social relationships influenced a sense of belonging in ways that aligned with previous studies (Baumeister \& Leary, 1995; DeWall \& Bushman, 2011; Hausmann et al. 2007; Hoffman et al., 2002/2003; Hurtado \& Carter, 1997; Johnson et al., 2007; Pittman \& Richmond, 2007; Strayhorn, 2008); however, student narratives suggest that the function of social relationships extends beyond the scope of friendship and support described in the literature. For our participants, social connections were more than vehicles for general social integration, and they served as only one piece of the belonging puzzle. Students did not just fit in or connect with friends: their relationships also contributed to the development of self-advocacy skills and academic mastery. In this study, important social relationships were fostered with peers with disabilities who could help participants articulate their needs. Social relationships fostered mastery of the student role as students worked together to develop strategies for self-advocacy and academic success. Positive connections with encouraging faculty and staff were also essential to the development of a sense of belonging. Thus, social relationships played a complex role in fostering belonging for these students, combining experiences of comfort and fitting in with more instrumental support that helped them gain confidence about their ability to "do college." While confidentiality issues prohibit disclosing a student's disability, university personnel can support the creation of optional student affinity organizations, support groups, or peer mentoring programs. Through such programs, students with disabilities can form friendships and share strategies for self-advocacy and mastering the student role, which, in turn, can foster a sense of belonging.

These findings affirm the importance of self-advocacy (Adams \& Proctor, 2010; Daly-Cano et al., 2015; Hadley, 2006; Janiga \& Costenbader, 2002; Webster, 2004) and extend the literature by highlighting a direct connection between self-advocacy and the development of a sense of belonging. Student narratives also suggest that self-advocacy leads to greater mastery of the student role, which aligns with the literature showing how effective self-advocacy relates to collegiate adjustment and academic achievement; yet some scholars (Daly-Cano et al., 2015; Janiga \& Costenbader, 2002) suggest many first-year students can be unprepared to effectively or proactively self-advocate. Higher education professionals should offer selfadvocacy workshops for new students where they can develop and practice strategies they 
need to advocate with faculty, staff, and peers. Upper-class students with disabilities could be invited to share their diverse self-advocacy journeys with new students.

Findings related to mastery of the demands of the student role affirm the limited literature that highlights the relationship between academic success and belonging (Pittman \& Richmond, 2007; Summers \& Svinicki, 2007). In this article, we use the term student role (vs. academic success) to explicate a complicated phenomenon that includes academic success (grades), task mastery, recognition, and the feeling of being a normal or legitimate college student. While disability services offices often focus on providing accommodations so that students can be academically successful, the mastery theme went beyond earning good grades. Disability services offices and other student affairs professionals should consider how important mastery is to students with disabilities. They must recognize that notions of mastery exist against a sociopolitical backdrop where students with disabilities receive explicit and implicit messages that they are "less capable" (Charlton, 2006, p. 220) and, thus, are not legitimate students. If students' sense of mastery of the student role enhances their sense of belonging, all student affairs practitioners (including disability services) must recognize the power they have to convey implicit and explicit messages about a student's ability to successfully navigate the student role. Inclusive practice requires disability consciousness and self-awareness of practitioners who oversee programming and service delivery (Evans \& Herriott, 2009; Olkin, 1999). Individuals with disabilities are often viewed through a deficit lens (Olkin, 1999), emphasizing conditions that suggest something is wrong with these students. In contrast to deficit notions, students in this study exhibited resiliency and effective coping strategies to master the student role.
To promote a sense of belonging among students with disabilities, professionals should emphasize and celebrate student strengths and engage in intentional advising and programmatic efforts to support students in their quest to master the student role. This can be achieved by formal programmatic efforts or informal conversations. For instance, student affairs professionals should approach dialogues with students by first asking about their unique goals and how well they feel they have self-advocated and mastered the student role. Such a perspective is in stark contrast to a deficit one where conversations begin with a focus on challenges, hurdles, or how well other people have provided accommodations.

\section{LIMITATIONS}

Our understanding of the process of achieving a sense of belonging for college students with disabilities is based on our conversations with a small group of students with largely invisible disabilities. As the literature suggests, their experiences might differ from those of students with disabilities that are visible to others (e.g., mobility impairments; Evans \& Herriott, 2009; Olkin, 1999). Similarly, since only one of our students encountered limited mobility issues, we cannot know if, or how, the physical environment and campus accessibility might influence the sense of belonging for students with other types of disabilities.

All of our participants self-identified with the Office of Disability Services at one campus. Research has shown that many college students do not self-identify as having a disability, while others go undiagnosed (Wagner et al., 2005). Among students who registered with the Office of Disability Services, we only spoke to students who volunteered to participate in our study and who were enthusiastic about sharing their belonging experiences. We did not interview students who described themselves 
as feeling severely alienated from the university or who dropped out.

In the future, longitudinal studies could clarify what happens to students' sense of belonging over the course of their college career. That said, we believe that our model, rooted deeply in student narratives, provides a solid foundation upon which more comprehensive developmental theories can be built.

Correspondence concerning this article should be addressed to Annemarie Vaccaro, Department of Human Development and Family Studies, University of Rhode Island, Kingston, RI 02881; avaccaro@uri.edu

\section{REFERENCES}

Adams, K. S., \& Proctor, B. E. (2010). Adaptation to college for students with and without disabilities: Group differences and predictors. Journal of Postsecondary Education and Disability, 22, 166-184.

Americans With Disabilities Act, 42 U. S.C. A. $\$ 12101$ et seq. (1990).

Americans With Disabilities Amendments Act, Pub. L. No. 110-325, 29 U. S.C. S. $\$ 705$ (2008).

Ames, C. (1992). Goals, structures, and student motivation. Journal of Educational Psychology, 84, 261-272.

Ashby, C. E., \& Causton-Theoharis, J. (2012): Moving quietly through the door of opportunity: Perspectives of college students who type to communicate. Equity \& Excellence in Education, 45, 261-282.

Barnard-Brak, L., Lechtenberger, D., \& Lan, W. Y. (2010). Accommodation strategies of college students with disabilities. Qualitative Report, 15, 411-429.

Baumeister, R. F., \& Leary, M. R. (1995). The need to belong: Desire for interpersonal attachments as a fundamental human motivation. Psychological Bulletin, 117, 497-529.

Belch, H. A. (2011). Understanding the experiences of students with psychiatric disabilities: A foundation for creating conditions of support and success. In M. S. Huger (Ed.), New Directions for Student Services: No. 134. Fostering the increased integration of students with disabilities (pp. 73-94). Hoboken, NJ: Wiley Periodicals.

Belch, H. A., \& Marshak, L. E. (2006). Critical incidents involving students with psychiatric disabilities: The gap between state of the art and campus practice. NASPA Journal, 43, 464-483.

Bryan, A., \& Myers, K. A. (2006, September-October). Students with disabilities: Doing what's right. About Campus, 18-22.

Burke, L. A., Friedl, J., Rigler, M. (2010). The 2008 Amendments to the Americans with Disabilities Act: Implications for student affairs practitioners. Journal of Student Affairs Research and Practice, 47, 63-77.

Charlton, J. I. (2006). The dimensions of disability oppression: An overview. In L. J. Davis (Ed.), The disability studies reader (2nd ed., pp. 217-227). New York, NY: Routledge.

Creswell, J. W. (2007). Qualitative inquiry and research design: Choosing among five traditions (2nd ed.). Thousand Oaks, CA: SAGE.
Daly-Cano, M., Vaccaro, A., \& Newman, B. M. (2015). College student narratives about learning and using self-advocacy skills. Journal of Postsecondary Education and Disability, 28(2), 209-223.

DeWall, C. N., \& Bushman, B. J. (2011). Social acceptance and rejection: The sweet and the bitter. Current Directions in Psychological Science, 20, 256-260.

Evans, N. J., \& Herriott, T. K. (2009). Philosophical and theoretical approaches to disability. In J. L. Higbee \& A. A. Mitchell (Eds.), Making good on the promise: Student affairs professionals with disabilities (pp. 27-40). Lanham, MD: University Press of America.

Freeman, T. M., Anderman, L. H., \& Jensen, J. M. (2007). Sense of belonging in college freshmen at the classroom and campus levels. Journal of Experimental Education, 75, 203-220.

Getzel, E. E., \& Thoma, C. A. (2008). Experiences of college students with disabilities and the importance of self-determination in higher education settings. Career Development for Exceptional Individuals, 31, 77-84.

Glaser, B. G. (1992). Basics of grounded theory analysis. Mill Valley, CA; Sociology Press.

Glaser, B. G., \& Strauss, A. L. (1967). The discovery of grounded theory: Strategies for qualitative research. Chicago, IL: Aldine.

Hadley, W., M. (2006). L. D. students' access to higher education: Self-advocacy and support. Journal of Developmental Education, 30(2), 10-16.

Hausmann, L. R. M., Schofield, J. W., \& Woods, R. L. (2007). Sense of belonging as a predictor of intentions to persist among African American and White first-year college students. Research in Higher Education, 48, 803-839.

Hoffman, M., Richmond, J., Morrow, J., \& Salomone, K. (2002/2003). Investigating "sense of belonging" in first-year college students. Journal of College Student Retention, 4, 227-256.

Hurtado, S., \& Carter, D. F. (1997). Effects of college transition and perceptions of the campus racial climate on Latino students' sense of belonging. Sociology of Education, 70, 324-345.

Individuals With Disabilities Education Act, 20 U. S.C. $\$$ 1400 (1975).

Individuals With Disabilities Education Improvement Act, Pub. L. No. 108-446 (2004). 
Janiga, S. J., \& Costenbader, V. (2002). The transition for high school to postsecondary education for students with learning disabilities: A survey of college service coordinators. Journal of Learning Disabilities, 35, 462-468.

Johnson, D. R., Soldner, M., Leonard, J. B., Alvarez, P., Inkelas, K. K., Rowan-Kenyon, H. T., \& Longerbeam, S. D. (2007). Examining sense of belonging among first-year undergraduates from different racial/ethnic groups. Journal of College Student Development, 48, 525-542.

Jones, S. R., Torres, V., \& Arminio, J. (2006). Negotiating the complexities of qualitative research in higher education: Fundamental elements and issues. New York, NY: Routledge.

Locks, A. M., Hurtado, S., Bowman, N. A., \& Oseguera, L. (2008). Extending notions of campus climate and diversity to students' transition to college. Review of Higher Education, 31, 257-285.

Maestas, R., Vaquera, G. S., \& Zehr, L. M. (2007). Factors impacting sense of belonging at a Hispanic-serving institution. Journal of Hispanic Higher Education, 6, 237-256.

Megivern, D., Pellerito, S., \& Mowbray, C. (2003). Barriers to higher education for individuals with psychiatric disabilities. Psychiatric Rehabilitation Journal, 26, 217-231.

Núñez, A.-M. (2009). A critical paradox? Predictors of Latino students' sense of belonging in college. Journal of Diversity in Higher Education, 2, 46-61. doi:10.1037/a0014099

Olkin, R. (1999). What psychotherapists should know about disability. New York, NY: Guilford.

Olney, M. F., \& Brokelman, K. F. (2003). Out of the disability closet: Strategic use of perception management by select university students with disabilities. Disability \& Society, 18, 35-50.

Ostrove, J. M., \& Long, S. M. (2007). Social class and belonging: Implications for college adjustment. Review of Higher Education, 30, 363-389.

Parker, M., \& Flowers, L. A. (2003). The effects of racial identity on academic achievement and perceptions on campus connectedness on African American students at predominantly White institutions. College Student Affairs Journal, 22(2), 180-193.

Patton, M. Q. (2002). Qualitative research and evaluation methods (3rd ed.). Thousand Oaks, CA: SAGE.

Pittman, L. D., \& Richmond, A. (2007). Academic and psychological functioning in late adolescence: The importance of school belonging. Journal of Experimental Education, 75, 270-290.

Shepler, D. K., \& Woosley, S. A. (2012). Understanding the early integration experiences of college students with disabilities. Journal of Postsecondary Education and Disability, 25, 37-50.

Summers, J. J., \& Svinicki, M. D. (2007). Investigating classroom community in higher education. Learning and Individual Differences, 17, 55-67.

Stodden, R. A. (2000, April). Research findings brief: National center for the study of postsecondary edcuation supports (Study Area 4a, Volume 5). Retrieved from the Rehabiliation Research and Training Center at the University of Hawai'i at Manoa: http:// www.rrtc.hawaii.edu/documents/products/phase1/078-H01.pdf
Stodden, R. A., Conway, M. A., \& Chang, K. B. T. (2003). Findings from the Study of Transition, Technology and Postsecondary Supports for Youth With Disabilities: Implications for secondary school educators. Journal of Special Education Technology, 18(4), 29-44.

Strange, C. C. (2000). Creating environments of ability. In H. A. Belch (Ed.), New Directions for Student Services: No. 91. Serving students with disabilities (pp. 19-30).. San Francisco, CA: Jossey-Bass.

Strauss, A. L., \& Corbin, J. (1990). Basics of qualitative research: Grounded theory procedures and techniques. Newbury Park, CA: SAGE.

Strauss, A. L., \& Corbin, J. (1998). Basics of qualitative research: Techniques and procedures for developing grounded theory (2nd ed.). Thousand Oaks, CA: SAGE.

Strayhorn, T. L. (2008). Sentido de pertenencia: A hierarchical analysis predicting sense of belonging among Latino college students. Journal of Hispanic Higher Education, 7, 301-320.

Strayhorn, T. L. (2012). College students' sense of belonging: A key to educational success for all students. New York, NY: Routledge.

Test, D. W., Fowler, C. H., Wood, W., Brewer, D. M., \& Eddy, S. (2005). A conceptual framework of self-advocacy for students with disabilities. Remedial and Special Education, 26, 43-54.

Thoma, C. A., \& Wehmeyer, M. L. (2005). Self-determination and the transition to postsecondary education. In E. E. Getzel \& P. Wehman (Eds.), Going to college: Expanding opportunities for people with disabilities (pp. 49-68). Baltimore, MD: Brookes.

Tinto, V. (1987). Leaving college: Rethinking the causes and cures of student attrition. Chicago, IL: University of Chicago Press.

Troiano, P. F. (2003). College students and learning disability: Elements of self-style. Journal of College Student Development, 44, 404-419.

Vickerman, P., \& Blundell, M. (2010). Hearing the voices of disabled students in higher education. Disability \& Society, 25, 21-32.

Wagner, M., Newman, L., Cameto, R., Garza, N., \& Levine, P. (2005). After high school: A first look at the postschool experiences of youth with disabilities. A report from the National Longitudinal Transition Study-2 (NTLS2). Menlo Park, CA: SRI International.

Webster, D. D. (2004). Giving voice to students with disabilities who have successfully transitioned to college. Career Development for Exceptional Individuals, 27, 151-175.

Wessel, R. D., Jones, J. A., Markle, L., \& Westfall, C. (2009). Retention and graduation of students with disabilities: Facilitating student success. Journal of Postsecondary Education and Disability, 21, 116-125. 